\title{
歯周疾患（慢性辺縁性歯周炎）患者の 初診時診査項目に関する検討
}

第 4 報 歯肉出血指数について

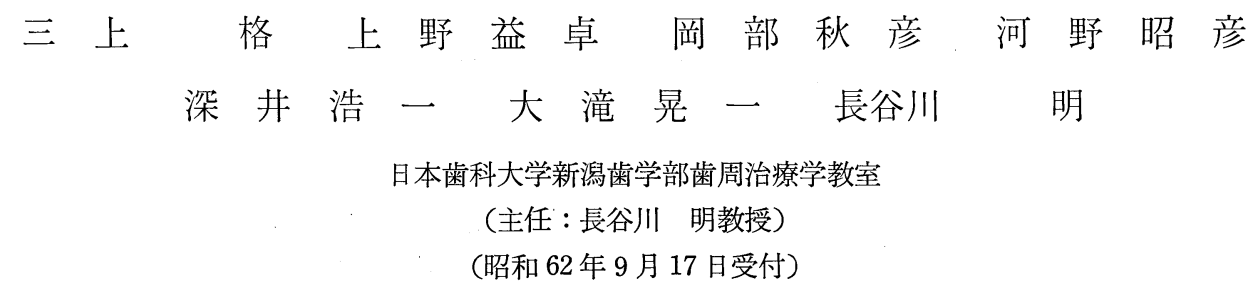

The State of Periodental Patients on Initial Visits

4. Bleeding Index

Itaru MIKAMI, Masutaka UENO, Akihiko OKABE, Akihiko KOUNO, Koichi FUKAI, Koichi OTAKI and Akira HASEGAWA

Department of Periodontics, The Nippon Dental University, School of Dentistry at Niigata (Chief : Prof. Akira HASEGAWA)

The purpose of this study was to investigate the bleeding index in 200 patients (100 males, $100 \mathrm{fe}$ males) who were diagnosed as having chronic marginal periodontitis at the initial visit. The average bleeding index was $24.5 \%$, and in $72.5 \%$ of the patients the bleeding index was from $0 \%$ to $29.0 \%$.

No significant differences were found in the bleeding index of males and females, or between age groups.

As prognosis of the patients' disease, the bleeding index increased as mild (periodontitis) $16.4 \%<\bmod$ erate $21.4 \%<$ severe $28.0 \%$.

A questionnaire for patients indicated that the bleeding index of patients who had the gingival bleeding, gingival swelling, gingival bleeding on brushing, and masticatory disturbances were higher than others. Also the bleeding index of patients who were scaled and had gingival treatment was also higher.

In the relation to the brushing times per day, the bleeding index was less as the patient's brushing time decreased : 3 times per day : $27.0 \%>2$ times : 24.6 $\%>1$ time : $24.0 \%$.

The patients who wanted to get preventive treatment showed low bleeding indexes.

A significant positive correlation was found $(\mathrm{P}<$ 0.01 ) between the bleeding index and the plaque control record, modified C.I.-S.

Key words : Bleeding Index, Chronic marginal periodontitis, Questionnaire for periodontal patients

要旨 : 慢性辺縁性歯周炎患者 200 名の初診時の歯肉出血指数につき検索を行った。その結果, 初診時の B.I. の平 均は $24.5 \%$ で，0〜 29\% が全体の $72.5 \%$ を占めていた。男女別にみた B.I. の比較では有意差を認めなかった。

疾患の進行度との関係では, 軽度 $16.4 \%$ <中等度 $21.4 \%$ <重度 $28.0 \%$ と進行するにつれ B.I. が高くなる傾向を 認めた。 
質問調査表との関係では, 歯肉出血, 歯肉腫脹, ブラッシング時の歯肉出血, 咀嚼障害を自覚する者, スケーリン グ，歯肉の治療の既往のある者の B.I. は比較的高い值を認めた。

1 日のブラッシング回数との関係では, 1 日 3 回 $27.0 \%>2$ 回 $24.6 \%>1$ 回 $24.0 \%$ とブラッシング回数が少なくな るにつれて B.I. が低くなる傾向を認めた。

治療に対する熱意では，予防を含めた治療を希望する者は B.I. が低い值を示した。

プラーク付着状態, 歯石付着状態と B.I. との間に危険率 $1 \%$ 以下で有意差を認め, B.I. と P.C.R., B.I. と modified $\mathrm{CI}-\mathrm{S}$ の間に正の相関関係を認めた。

索引用語 : 歯肉出血指数, 慢性辺縁性歯周炎, 歯周疾患患者質問調査表

\section{緒言}

歯肉の炎症の程度を把握することは，歯周組織の状態 を知る上で重要である。

しかし，歯肉部における初期の炎症性変化を，歯肉の 色，形態また歯周ポケットの存在などから知ることはき わめて困難なことである。他方, 歯肉溝内からの出血は, 臨床的変化が明らかに認められる以前から存在する炎症 的特徴の 1 つとして考えられている1)。

われわれは，歯周疾患のうち最む頻度の高い慢性辺縁 性歯周炎罹患患者が，ぞのような状態で来院するのかを 把握すべく検討を進めて扔り，第 1 報 歯周疾患患者質 問調查表 ${ }^{2}$ ，第 2 報 プラーク付着状態3)，第 3 報 歯石 付着状態 $)$ について検討し報告した。今回, 歯周疾患患 者の来院時の歯肉出血指数について, 疾患の進行度との 関係，また，歯周疾患患者質問表の各項目との関係，プ ラーク付着状態, 歯石付着状態との関係について検索し たのでここに報告する。

\section{調查対象および調查方法}

\section{1. 調査対象}

昭和 57 年 6 月から昭和 59 年 2 月までの間に日本歯科
大学新潟歯学部付属病院歯周治療科に来院した患者のう

ち, 慢性辺縁性歯周炎と診断された男性 100 名, 女性 100 名, 計 200 名を対象とした。

\section{2. 調查方法}

歯肉出血指数 Bleeding Index (以下, B.I. と略す) は 各歯の歯周ポケット部を近心，遠心，唇頓側，舌口蓋側 の 4 部に分割し，それぞれの部位について歯周ポケット をプロービングし出血があるかないかを判定し，チャー ト（図 1) に記入し，つぎの式で評価した。

$\underset{(\%)}{\text { B.I. 值 }}=\frac{\text { 出血したポケット部の合計 }}{\text { 被検ポケット部の数 }} \times 100$

なお，歯周ポケット測定器は，日歯大新潟式（山浦製 作所製, 先端の直径 $0.5 \mathrm{~mm}$ ）を使用し，これを歯周ポ ケット底部に挿入し，歯面に沿ってゆるやかに動かし出 血の有無を評価した。その測定時の圧は約 $25 \mathrm{~g} と し ，$ また出血のある迄の時間は設定せず行った。

調查に先立って当科で行っている B.I. の有効性を立 証するため, すでに歯肉炎の程度を評価する指数として 有効性が認められている Löe と Silness の Gingival In$\mathrm{dex}^{5)}$ との相関関係について検索を行った。

Gingival Index と B.I. との散布図は図 2 のごとく, 相関係数 0.94 で, 相関係数の検定の結果, 危険率 $1 \%$ 以 下で有意差が認められ, Gingival Index と B.I. は正の 相関関係であることが判明した。

\section{歯肉出血指数}

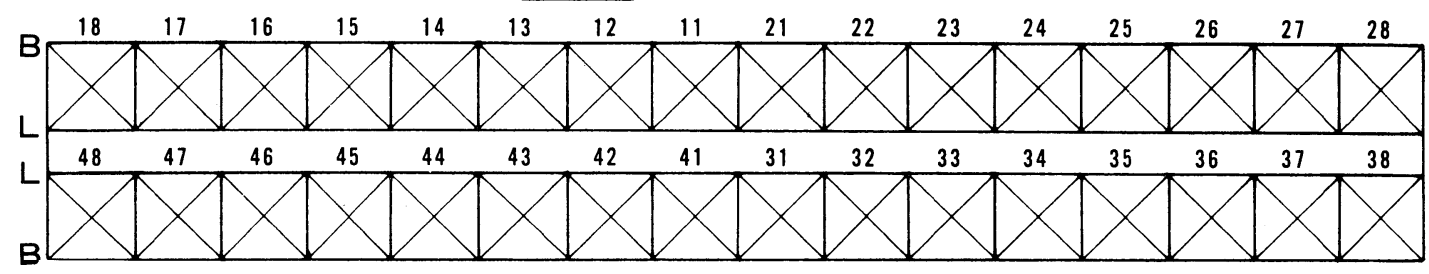

図 1 歯肉出血指数 (Bleeding Index) チャート 


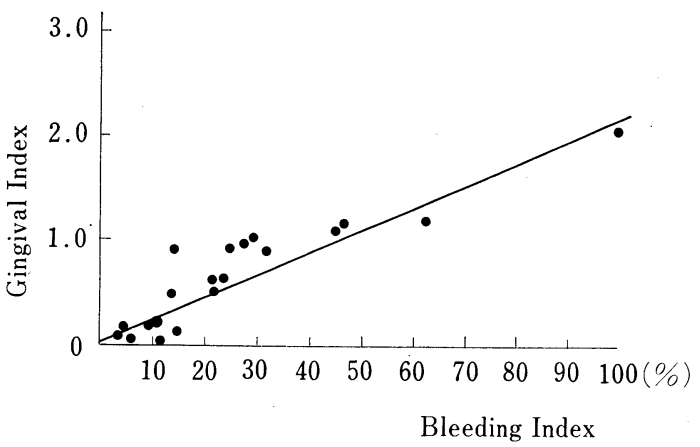

図 2 Gingival Index と Bleeding Index

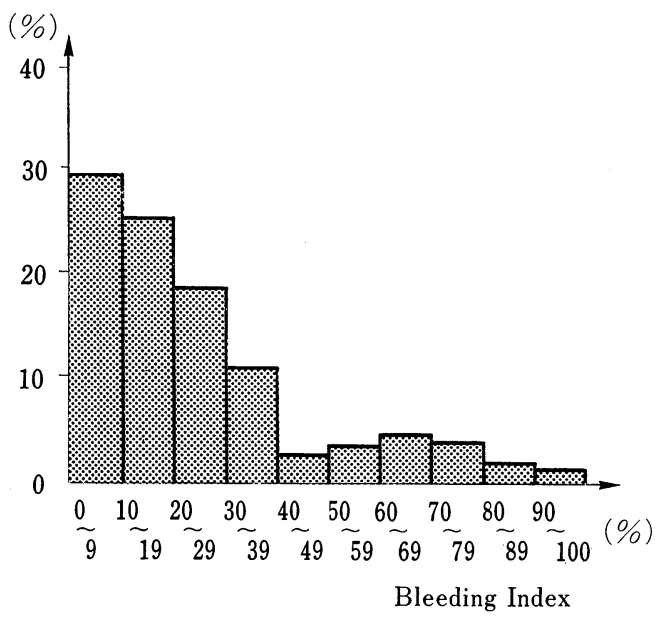

図 3 初診時 Bleeding Index

これによって B.I. の有効性が確認された。

\section{結果}

\section{1. 初診時 B.I. の分布}

歯周疾患患者の初診時の B.I. の平均は $24.5 \%$ であり, B.I. が 0〜9\% は $29.5 \%, 10 〜 19 \%$ が $25.0 \%, 20 〜 29 \%$ $18.0 \%$ の順で，0～ $29 \%$ が全体の $72.5 \%$ を占めていた (図 3)。しかし，これらの間に統計的有意差は認められ なかった。

\section{2. 男女別にみた B.I.}

男女別に B.I. の比較を行った。その結果, 男性の B.I. の平均は $22.8 \%$, 女性が $26.2 \%$ であり，また男性では 0〜9\% 代, 女性では 10～19\% が最も多かった。女性に B.I. が高い傾向を示したが, 統計的有意差は認められな かった (図 4)。
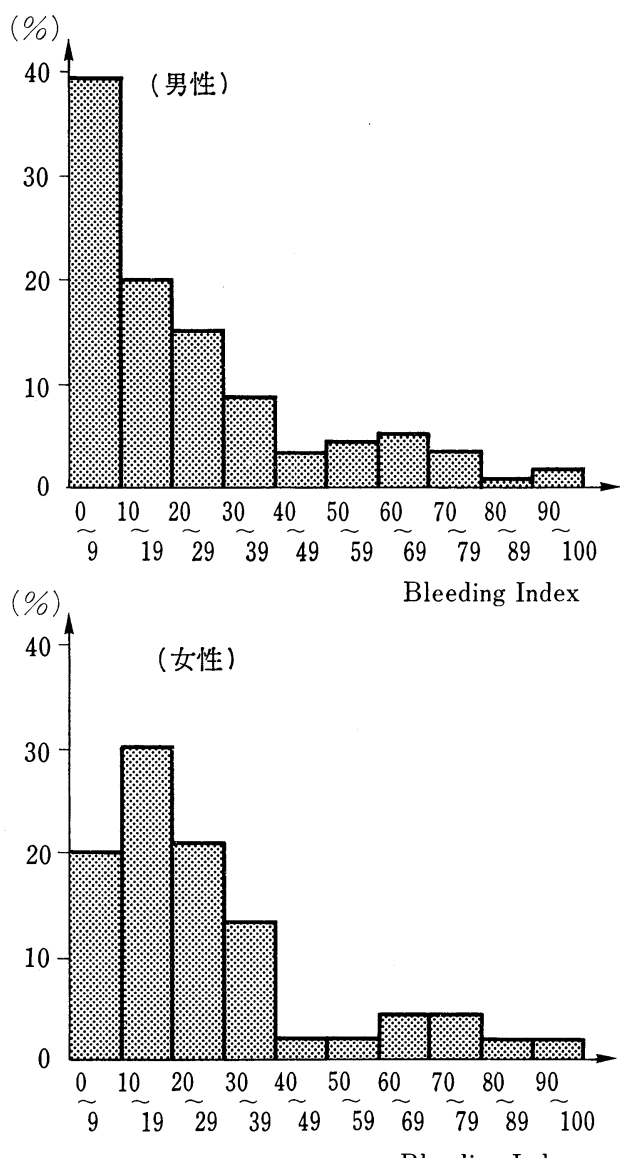

Bleeding Index

図 4 男女別にみた Bleeding Index

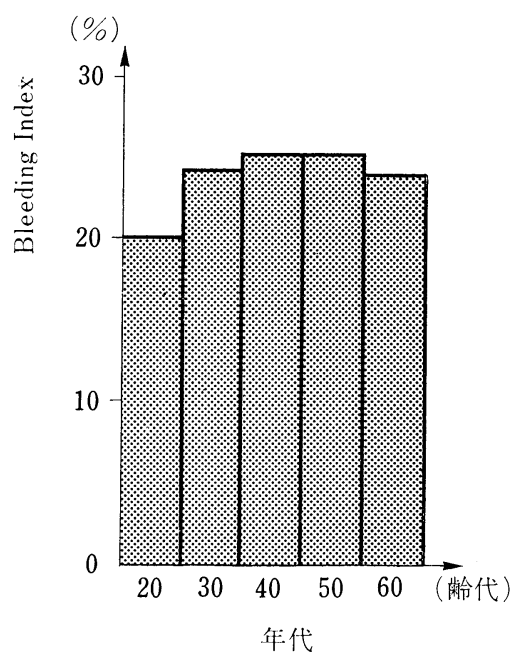

図 5 年代別にみた Bleeding Index 
表 1 疾患の進行度の判定基準

\begin{tabular}{c|c|c}
\hline & 歯周ポケットの深さ $(\mathrm{mm})$ & 動摇度 \\
\hline 軽 度 & $1 \sim 3$ & 1 度 \\
\hline 中等度 & $4 \sim 6$ & 2 度 \\
\hline 重 度 & $7 \sim 12$ & 3 度 \\
\hline
\end{tabular}
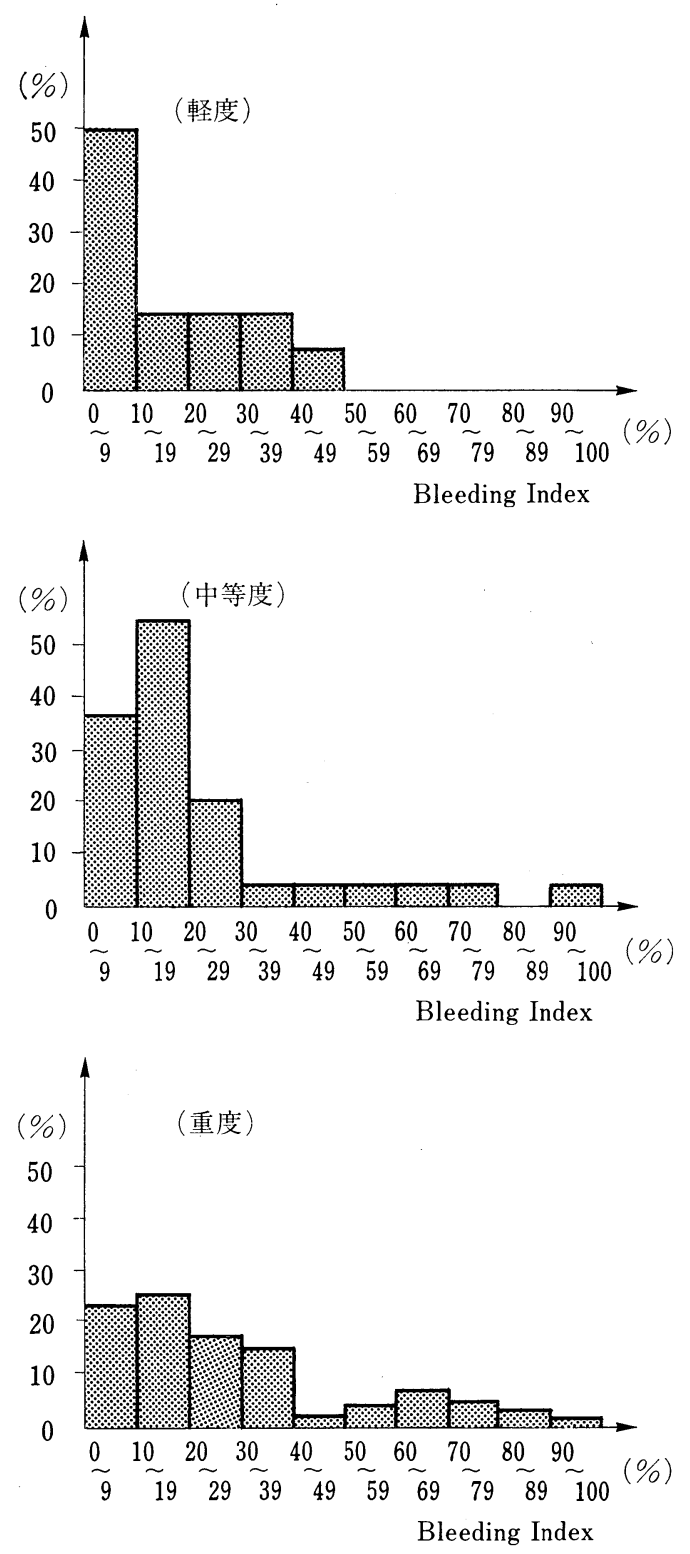

図 6 疾患の進行度と Bleeding Index

\section{3. 年代別にみた B.I.}

年齢により B.I. の平均の差がみられるか否かについ ても調べてみた。その結果 40 歳代と 50 歳代が $25.4 \%$, 30 歳代 $24.4 \%, 60$ 歳代 $24.2 \%, 20$ 歳代 $20.0 \%$ と年齢に よる差はほとんど認められず，統計的有意差も認められ なかった (図 5)。

\section{4. 疾患の進行度と B.I.}

当科では, 慢性辺縁性歯周炎の進行度を, 歯周ポケッ 卜の深さと動摇度により, 軽度, 中等度, 重度の 3 段階 に分類している（表 1)。

これにより分類された疾患の進行度別の B.I. の平均 を比較してみると, 軽度は $16.4 \%$, 中等度 $21.4 \%$, 重度 $28.0 \%$ と疾患が進行するにつれて B.I. が高くなる傾向 を認め，軽度と重度の間には， $\mathrm{t}$-検定により，危険率 $1 \%$ 以下で有意差が認められた。

またその分布に扔いても，軽度は 0 9\% 代が，中等度 では，10１9\% 代が最も多いが，重度では 0 90\% 代ま で平均して分布していた（図 6)。

\section{5. 歯周疾患患者質問調査表の各項目と B.I.}

歯周疾患患者質問診查表は, 39 項目からなる質問表で 診査の最初の手段として初診時の患者に記入してもらっ ている (表 2)。これにより患者の自覚症状, 啫好品, 習 慣, 過去に扔ける歯周治療の経験, 口腔衛生観念，治療 に対する熱意などの情報をある程度把握することが可能 である。これと B.I. との関係を検討してみた。

1）自覚症状との関係

過去において行った歯周疾患患者質問調査表による検 討においては患者の自覚症状のうち, B.I. に比較的関係 の深い，歯肉出血とブラシング時の歯肉出血を訴える者 は，それぞれ $63.0 \%$ と $70.5 \%$ と非常に高い割合で主訴 となる場合が多く，歯肉よりの出血は比較的患者自身も 自覚しやすい症状であることがわかった。

しかし B.I. の平均は歯肉出血 $25.9 \%$, 歯肉腫脹 27.5 $\%$, ブラッシング時の歯肉出血 $24.2 \%$, 咀嚼障 害 28.1 \%と比較的高い值がみられたが，その他の項目と同様で あり有意差は認められなかった（表 3 )。

また自覚症状による B.I. の分布を比較したが分散は 等しく有意差は認められなかった（図 7-1,7-2, 7-3）。

2）習慣および墸好品との関係

硬固物を好む患者の B.I. の平均は $15.4 \%$ であり有意 に低い値を示した。

また口呼吸をする患者は $26.6 \%$ と比較的高い值を示 し，口呼吸患者では歯肉炎が強いことが示唆された（表 4 , 図 8)。 
表 2 歯周疾患患者質問調査表

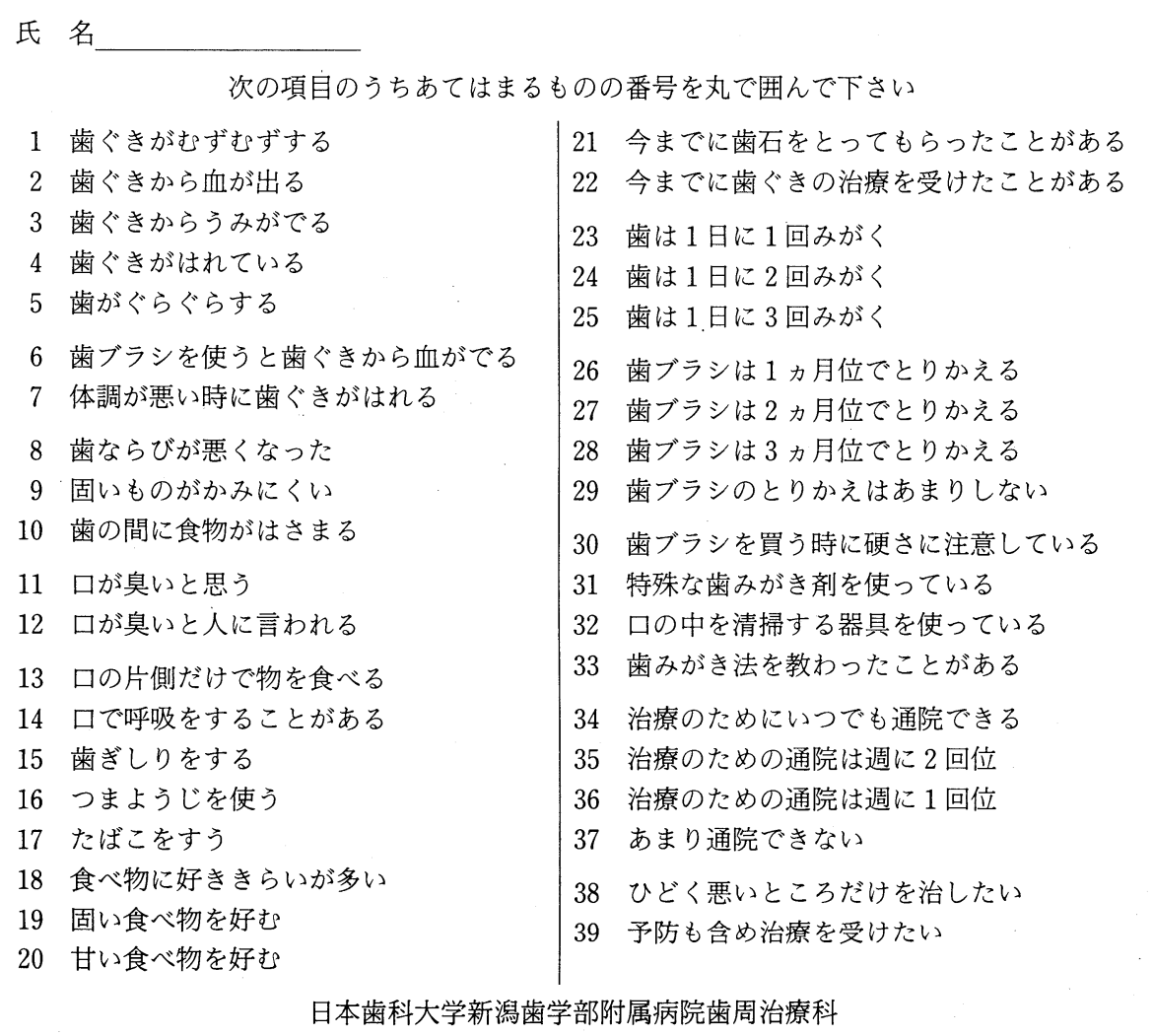

表 3 自覚症状と Bleeding Index

\begin{tabular}{l|l}
\hline 歯肉の違和感 & $23.6(\%)$ \\
歯肉出血 & 25.9 \\
歯肉からの排膿 & 24.2 \\
歯肉腫脹 & 27.5 \\
歯の動摇 & 24.4 \\
ブラッシング時の歯肉出血 & 24.2 \\
体調悪化時の歯肉腫脹 & 24.1 \\
歯の移動 & 22.8 \\
咀嚼障害 & 28.2 \\
食片圧入 & 25.1 \\
自覚的口臭. & 26.8 \\
他覚的口臭 & 26.6 \\
\hline
\end{tabular}

3）過去における治療経験と B.I.

スケーリングの既往と歯肉の治療の既往のある患者の B.I. の平均は，それぞれ $27.1 \%, 26.0 \%$ と比較的高い值 を示したが, 統計的有意差は認められなかった（表 5 ,
表 4 習慣·嗜好品と Bleeding Index

\begin{tabular}{l|l}
\hline 片側咀嚼 & $26.1(\%)$ \\
口呼吸 & 26.6 \\
歯ぎしり & 22.6 \\
つまようじの使用 & 23.4 \\
喫 煙 & 21.9 \\
偏 食 & 15.9 \\
硬固物の摂取 & 15.4 \\
甘味物の摂取 & 26.7 \\
\hline
\end{tabular}

表 5 過去における治療経験と Bleeding Index

\begin{tabular}{c|l}
\hline スケーリング & $27.1 （ \%)$ \\
歯肉の治療 & 26.0 \\
\hline
\end{tabular}

図 9)。

4） 1 日のブラッシング回数と B.I.

1 日のブラッシング回数は 1 日に 2 回のものが 44.2 \%, 1 回が $35.7 \%, 3$ 回が $20.1 \%$ と, 1 日に 2 回のものが 

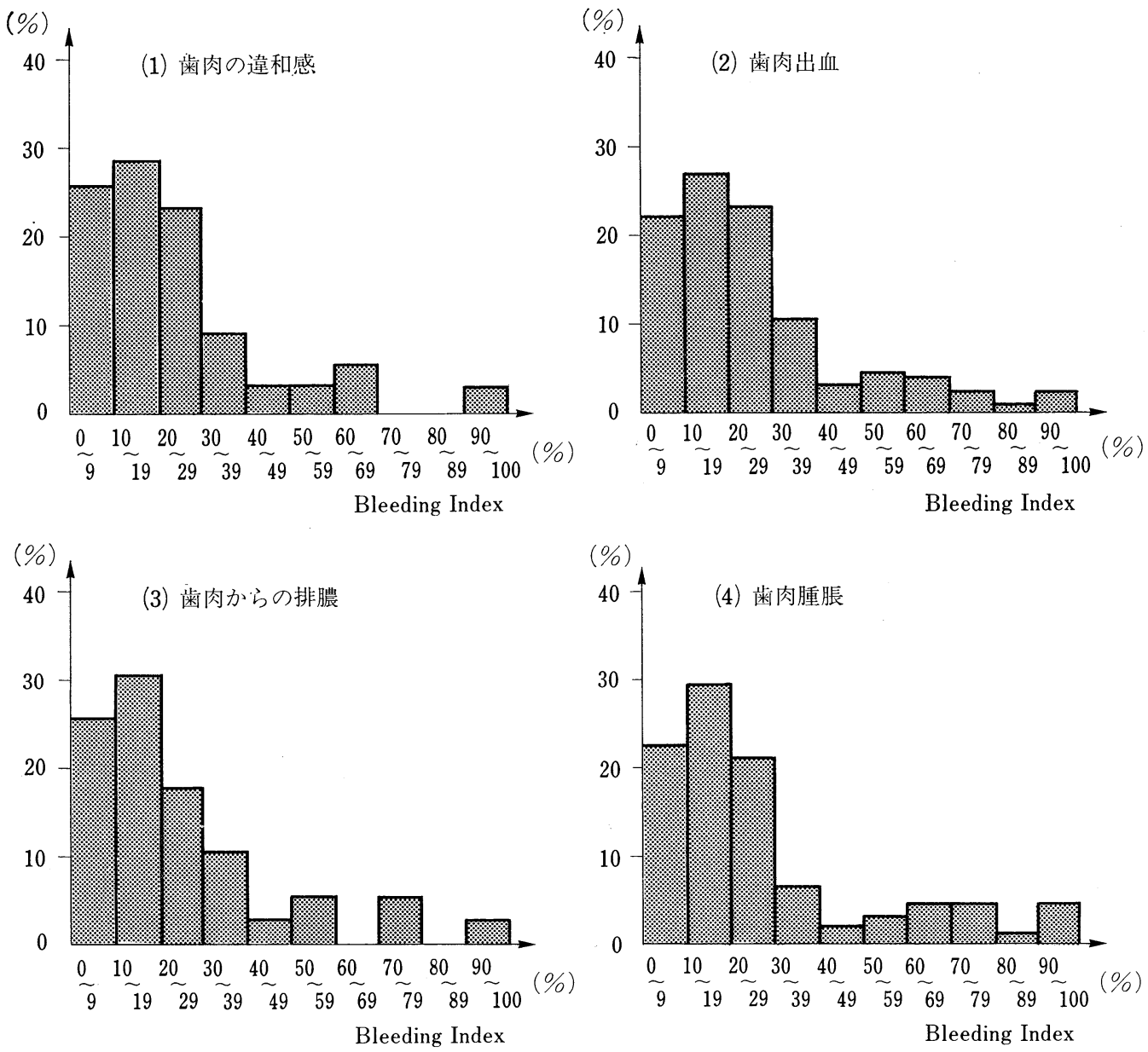

図 7-1 自覚症状と Bleeding Index

最も多かった。またそれらの B.I. の平均は, 3 回のもの が $27.0 \%$ と最も高く, 2 回 $24.6 \%, 1$ 回 $24.0 \%$ とブラ ッシング回数が少なくなるにつれて B.I. の值は低くな る傾向がみられた。

しかし，これらの間に有意差は認められなかった（表 6 , 図 10)。

5）歯ブラシの交換頻度と B.I.

歯ブラシの交換をあまりしない患者の B.I. の平均は $27.7 \%$ と最も高く, やはり口腔清掃やブラッシングに興 味のない患者は歯肉炎の程度も高いように思われた。

3 力月ぐらいで交換するものと， 2 力月，および， あ まり交換しないものとの間に, それぞれ危険率 5\% で t検定により有意差が認められた（表 7, 図 11）。

6）その他の口腔衛生観念と B.I.
表 61 日のブラッシング回数と BleedingIndex

\begin{tabular}{l|l}
\hline 1 回 & $24.0(\%)$ \\
2 回 & 24.6 \\
3 回 & 27.0 \\
\hline
\end{tabular}

表 7 歯ブラシの交換頻度と Bleeding Index

\begin{tabular}{l|l}
\hline 1 カ月に 1 回 & $21.2(\%)$ \\
2 カ月に 1 回 & 25.3 \\
3 カ月に 1 回 & 17.3 \\
あまりしない & 27.7 \\
\hline
\end{tabular}



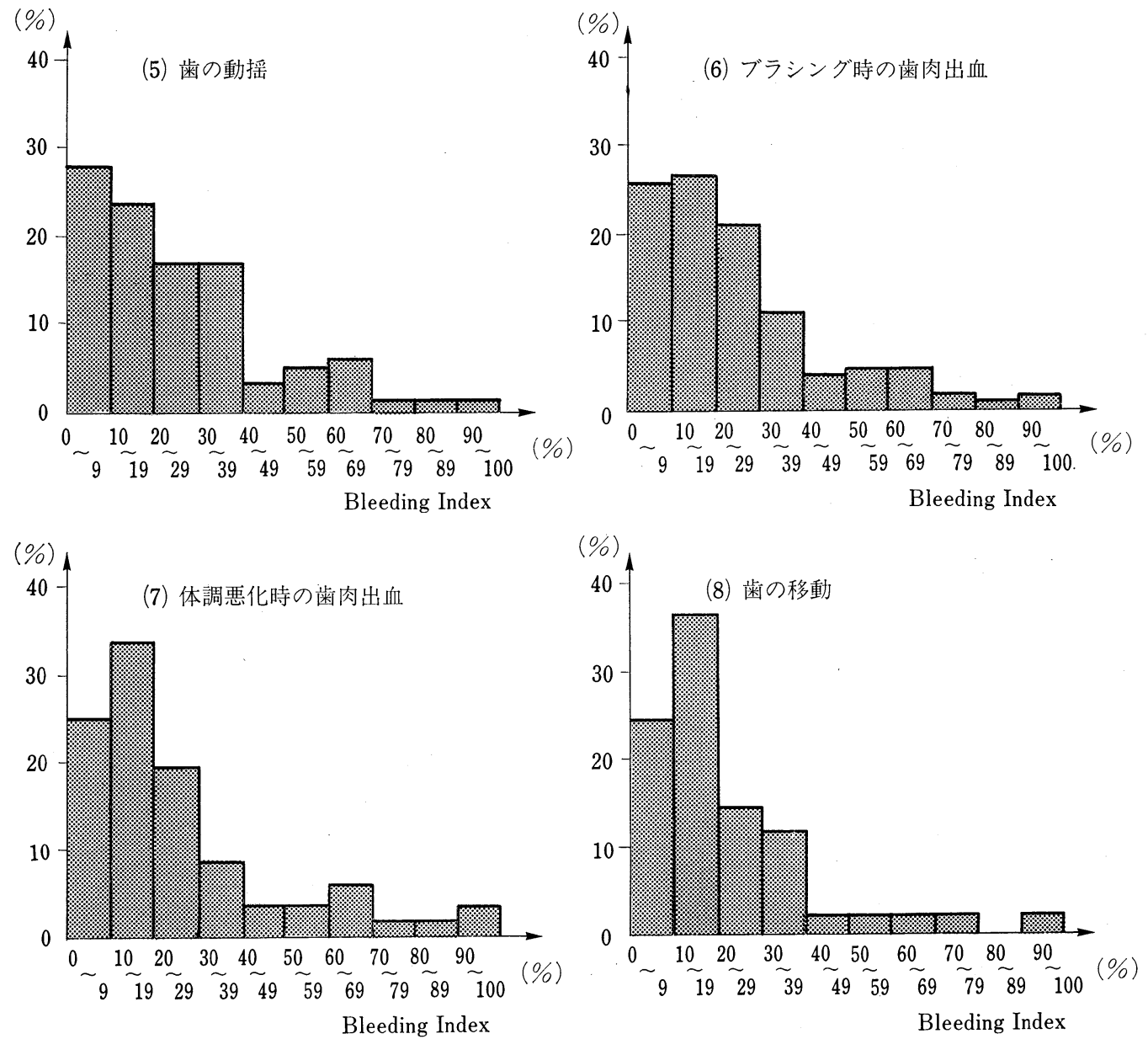

図 7-2 自覚症状と Bleeding Index

特殊な歯磨剤を使用している患者, 通常の歯ブラシ以 外の清掃器具を使用している患者の B.I. の平均はいず れも $18.3 \%$ と低い值を示し, 口腔衛生観念の高い患者 はやはり歯肉の炎症の程度も低いと考えられた。しか し, これらの間に統計的有意差は認められなかった（表 8, 図 12)。

7）治療に対する熱意と B.I.

予防を含めた治療を希望する患者の B.I. は $24.7 \%$ と， ひどく悪いところだけ治療を希望する患者の $26.4 \%$ よ り低い值を示したが, 有意差は認められなかった（表 9 , 四 13)。

\section{6. プラーク付着状態と B.I.}

すでに報告した初診時のプラーク付着状態 ${ }^{3)}$ と B.I. と の相関関係について検索を行った。
表 8 その他の口腔衛生観念と Bleeding Index

\begin{tabular}{l|l}
\hline 歯ブラシの硬さに注意 & $23.3(\%)$ \\
特殊な歯磨剤の使用 & 18.3 \\
通常の歯ブラシ以外の清掃器具の使用 & 18.3 \\
過去における TBI の経験 & 24.0 \\
\hline
\end{tabular}

表 9 治療に対する熱意と Bleeding Index

\begin{tabular}{l|l}
\hline ひどく悪いところだけの治療の希望 & $26.4(\%)$ \\
予防を含めた治療の希望 & 24.7 \\
\hline
\end{tabular}

B.I. と P.C.R. の散布図は図 14 のごとく, 相関係数 0.39 で, 相関係数の検定の結果, 危険率 $1 \%$ 以下で有意 差が認められ, B.I. と P.C.R. とには, 正の相関関係があ ることが明らかとなった。 

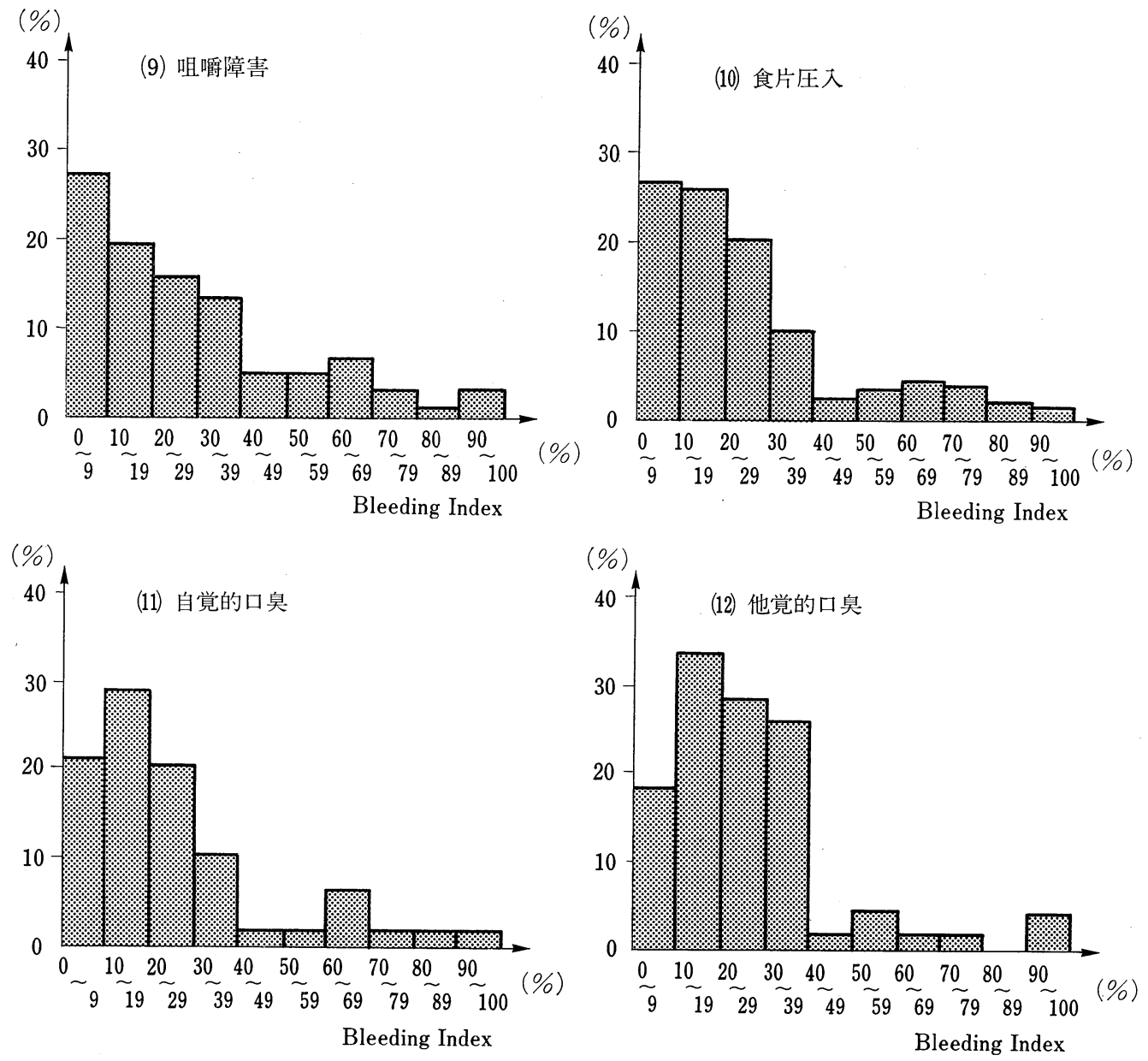

図 7-3 自覚症状と Bleeding Index

\section{7. 歯石付着状態亡 B.I.}

すでに報告した初診時の歯石付着状態) と B.I. との相 関関倸について検索を行った。

散布図は図 15 のごとく, 相関係数 0.34 で, 相関係数 の検定の結果, 危険率 $1 \%$ 以下で有意差が認められ, modified CI-S と B.I. との間に正の相関関係があるこ とが判明した。

\section{考察}

歯肉部の初期炎症状態を正確に表わす指数として, 種 々の Bleeding Index が報告されている。すなわち 1971 年 Mühlemann と Son ${ }^{6}$ は, 歯肉溝からの出血が歯肉炎 の初期における臨床的徴候であり, これは歯肉部の色の
変化, 腫脹に先行することを示し, プロービングした際 の歯肉溝からの出血と辺縁歯肉, 乳頭部歯肉の臨床所見 より評価する歯肉溝出血指数 Sulcus Bleeding Index (S.B.I.) について報告した。プロービングの方法として は, 先端が鈍な直径 $0.5 \mathrm{~mm}$ のプローブを使用して歯肉 溝部を静かにプロービングし 30 秒以内の出血の有 無で 判定している。

1975 年 Ainamo と $\mathrm{Bay}^{7)}$ は, 先端が鈍なプローブを 使用して, 歯肉溝の入り口を疼痛を感じない程度に静か にプロービングし, 10 秒以内に出血があった場合は $(+)$ と判定して, 診査した歯肉縁の数に対する百分比で表示 する歯肉出血指数 Gingival Bleeding Index (G.B.I.) について報告した。

1979 年 Van der Verden ${ }^{8)}$ は $0.75 \mathrm{~N}$ のカでプロービ 

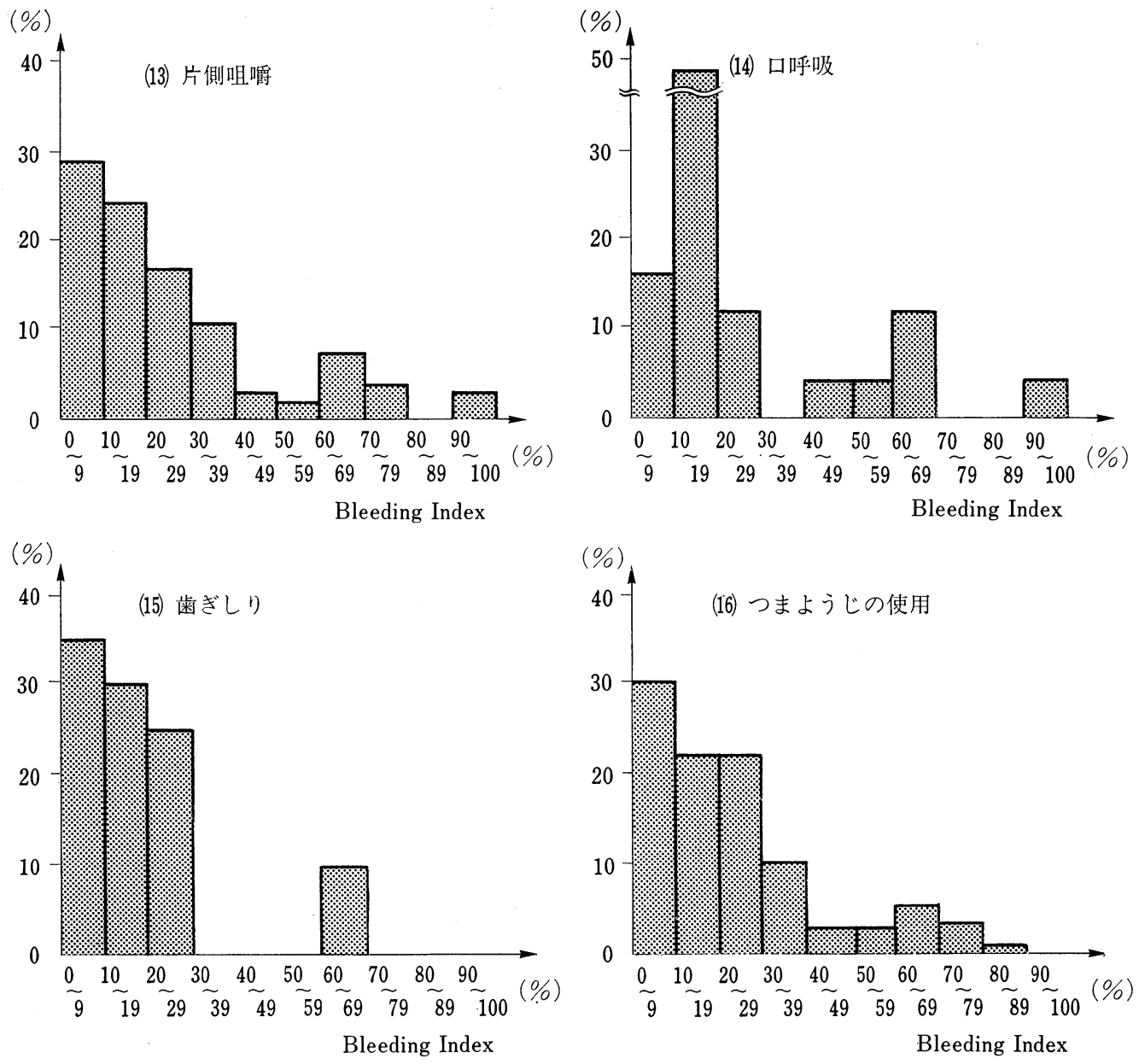

図 8-1習慣㧍よび嗜好品と Bleeding Index

ングし, その際のポケットからの出血傾向を歯周ポケッ 卜出血指数 Periodontal Pocket Bleeding Index (P.P. B.I.)として報告した。

一方，わが国においては，1981 年神山ら 9 が，先端が 鈍で直径 $0.5 \mathrm{~mm}$ の NORDENT 社製ポケット探針でポ ケットの測定を行い, 30 秒内にその部位に出血が認めら れた歯面数を, 測定した歯面数との百分比で表示する歯 肉出血指数 Bleeding Index (B.I.) を報告した。

1981 年高須賀ら ${ }^{10)}$ は, 日歯大式規格荷重プローブを用 いこれを $25 \mathrm{~g}$ の荷重で歯周ポケット内に挿入し，10～ 30 秒後の出血を 1 個あたり 4 面について診査し, 出血し た部位を $(+)$, 出血しなかった部位を $(-)$ として記録 する Gingival Bleeding Index (G.B.I.) について報告 した。
1983 年䞇ら ${ }^{11)}$ は，ヒューフレディ社製のプローブを用 い歯肉溝内壁をプローブの先端で軽く擦過し, 約 30 秒 後の出血の有無を判定する Bleeding Index (B.I.) につ いて報告した。

以上，が国における報告も含め Bleeding Index に ついて述べたが，それぞれの報告において使用するプロ ーブ, プロービングする部位（歯肉縁近接部か, 歯肉溝 内壁か, 歯肉溝底部かなど), 判定までの時間, プロービ ング圧などに相違がある。

一般にプロービング時の出血は，結合組織中のコラー ゲン線維の崩壊場所を示しており, 歯肉に炎症があれば, 結合組織中に無数の炎症性細胞浸潤がみられ，脈管の発 達が顕著となり, 結合組織, コラーゲン線維の崩壊によ りその場所に歯周ポケット測定器は深く入り, その結果 

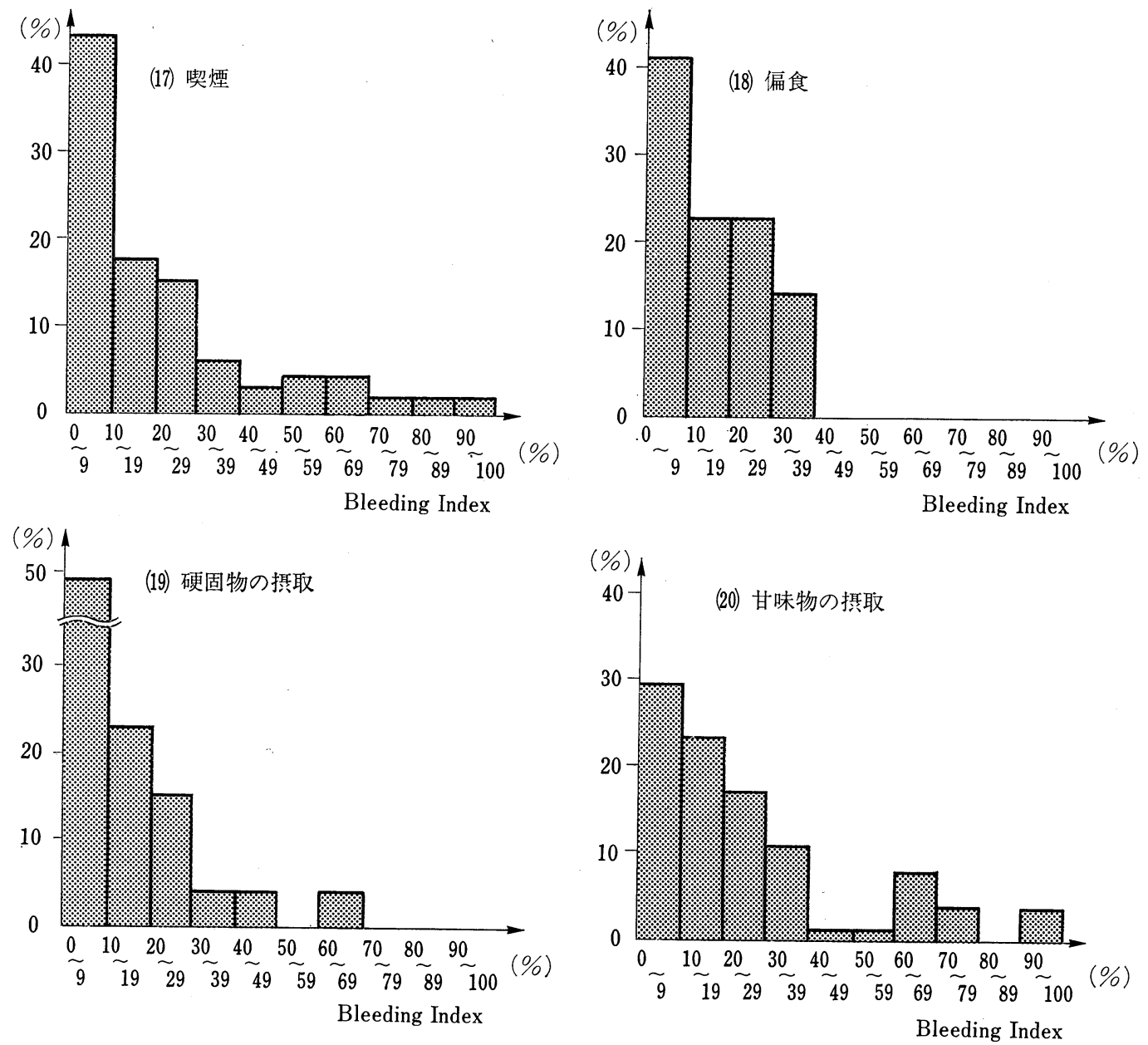

図 8-2 習慣および嗜好品と Bleeding Index
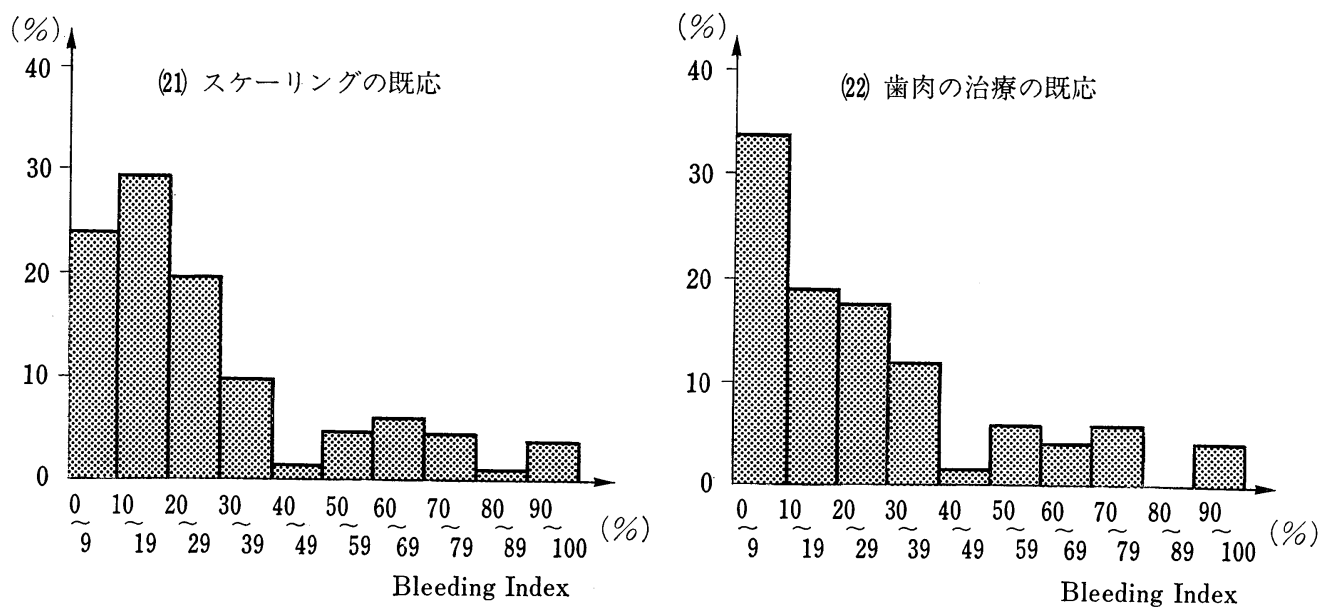

図 9 過去における治療経験と Bleeding Index 

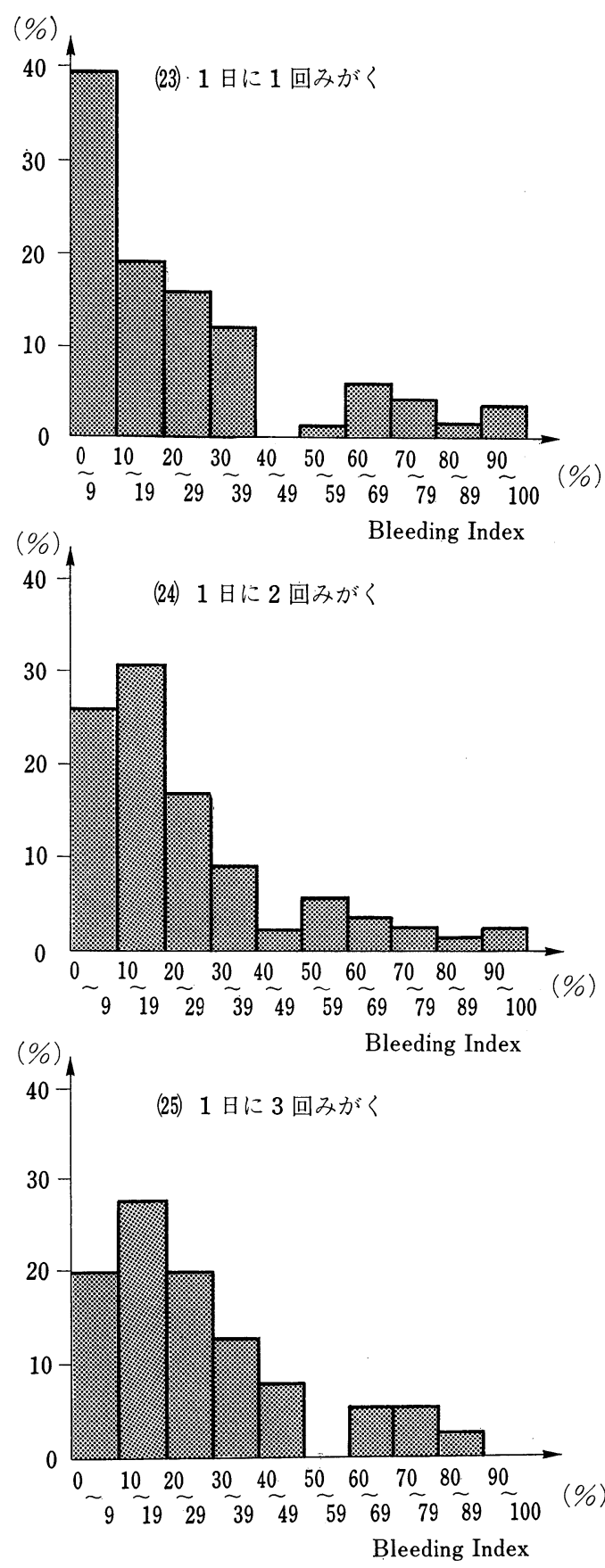

図 101 日のブラッシング回数と Bleeding Index

出血を認める。この場合, 歯周ポケット測定器の先端は 結合組織を突き破って接合上皮内にあり，このため組織 学的にはポケット底よりも深い位置に歯周ポケット測定 器の先端がある。一方健康な歯肉の結合組織は組織の抵
抗性と弾力があり，歯周ポケット測定器の先端は組織学 的ポケット底まで達せず出血を認めないと考えられてい る $^{12)}$ 。

同様にプロービング時の歯周ポケット測定器の先端の 正確な位置について多くの報告があるが13 15), Polson と Goodson ${ }^{16)}$ はこれらの研究を踏まえて, 歯周ポケット測 定器の穿通する深さと臨床組織学的炎症症状との関係を より明らかにする必要があると述べている。

Listgarten $^{17)}$ は, プロービングの測定值を左右する要 因として, (1) 使用する歯周ポケット測定器の深さ, (2) 歯 の解剖学的特徴たとえば歯面の豊隆による歯周ポケット 測定器の挿入角度, (3) プロービングの圧力, (4) 炎症の 程度などであるとしており,さらに適切な器具を選択し， 注意深く診查を行えば歯周ポケット測定器の厚さや歯面 の豊隆や不適当な歯周ポケット測定器の挿入角度などの 因子による測定の誤差をより減少させたり回避できる が，プロービングの力のばらつきや歯周組織の炎症性変 化の広がりによって生ずる誤差を避けることはさらに困 難であると述べている。

これに関連して Freed ら ${ }^{18)}$ は, 歯周病専門医 13 名, 一般歯科医 15 名, 歯科衛生士 15 名, 歯科大学生 15 名, 合計 58 名を対象としたプロービングの研究において5 $135 \mathrm{~g}$ と広い差を認め, 前歯部より臼歯部に強く, 3 点中 では遠心>近心 >中央部とプロービング圧に強弱が出る とし,さらに同じ歯科医でも術前より術後のほうが probing depth をより浅く測定する傾向があると報告して いる。プロービング圧にはかなりの誤差があり，かつ熟 練を要すると考察できる。

そこで当教室では，これらの誤差を避け，かつ測定法 の簡便化をはかるため, 日常臨床で使用している歯周ポ ケット測定器を使用し， 4 点法で行う歯周ポケット測定 と同時に歯肉出血指数 Bleeding Index (B.I.) の検出を 行っている。本方法は歯周ポケット底より内壁におよぶ 全ポケットよりの出血の有無で\%を算出するもので, こ の際, 測定器を歯周ポケットに挿入する時の力を, 通常 の歯周ポケット測定時の圧とし, 出血までの時間に関係 なく出血の有無で判定している。この B.I. が歯肉炎の 程度を評価する指数として有効であることを立証するた め, Löe と Silness ${ }^{5)} の$ Gingival Index との相関関係を 検索した結果, 相関指数 0.94 で, 相関係数の検定の結果 危険率 $1 \%$ 以下で有意差が認められ, Gingival Index と B.I. とは正の相関関係であることが判明し有効性が確認 された。

Meitner $ら^{19)}$ は歯肉炎の早期発見に, 視診による変化 

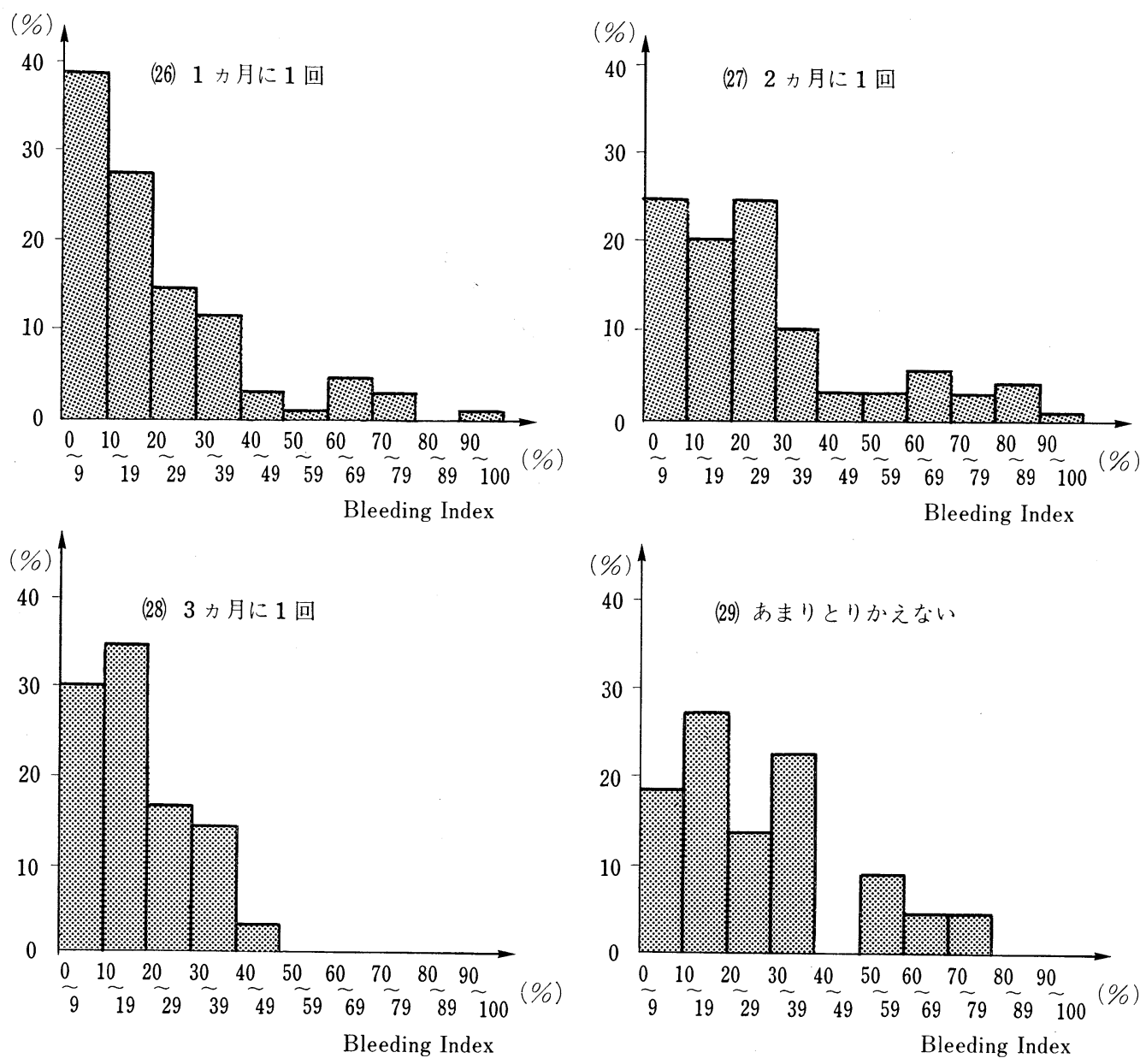

図 11 歯ブラシの交換頻度と Bleeding Index

よりもプロービングによる出血の方が鋭敏に反応し，確 実な診査法であると報告しており，本邦でも神山ら ${ }^{9)}$ ヒトの実験的歯肉炎を対象とした Bleeding Index につ いての研究で, Bleeding Index は歯肉溝滲出液量との間 に強い相関関係があり，また Bleeding Index は Gingival Index や P.M.A. Index と比較して術式が簡単で術 者の主観が入りにくい点などすぐれており, かつ P.M. A. Index で検出される以前の歯肉炎を発見する指標と して Bleeding Index が役立つであろうと示唆している。 そして, 来院直前のブラシの使用の有無にかかわらず, より正確な測定ができるとしており, Bleeding Index は 歯肉炎の消長や程度を評価する指数として使用できるで あろうと結論づけている。

同様に䞇ら ${ }^{11)}$ は，ブラッシングを中止することにより
発症させたヒトの実験的歯肉炎を対象として, その発症 と治癒過程における Plaque Index, Gingival Index, 歯肉溝滲出液量の変動を追求し, その結果, Plaque 蓄積 期と除去期において Plaque Index と Bleeding Index, Gingival Index との間に正の相関関係があるとし，初 期歯肉炎の歯肉組織の炎症状態を評価する方法として Bleeding Index は極めて鋭敏な方法であり,また Bleeding Index の上下頡 12 前歯の測定に約 $2 \sim 3$ 分要し, 極 めて短時間であり有用な評価方法であると報 告してい る。

また渡辺ら 20$)$ は, Gingival Bleeding Index と probing depthとの間に正の相関関係があり，ポケット内の炎症 度と probing depth は関連深く, probing depth 值が 増加するにつれて出血率も増す傾向がみられ, さらに 

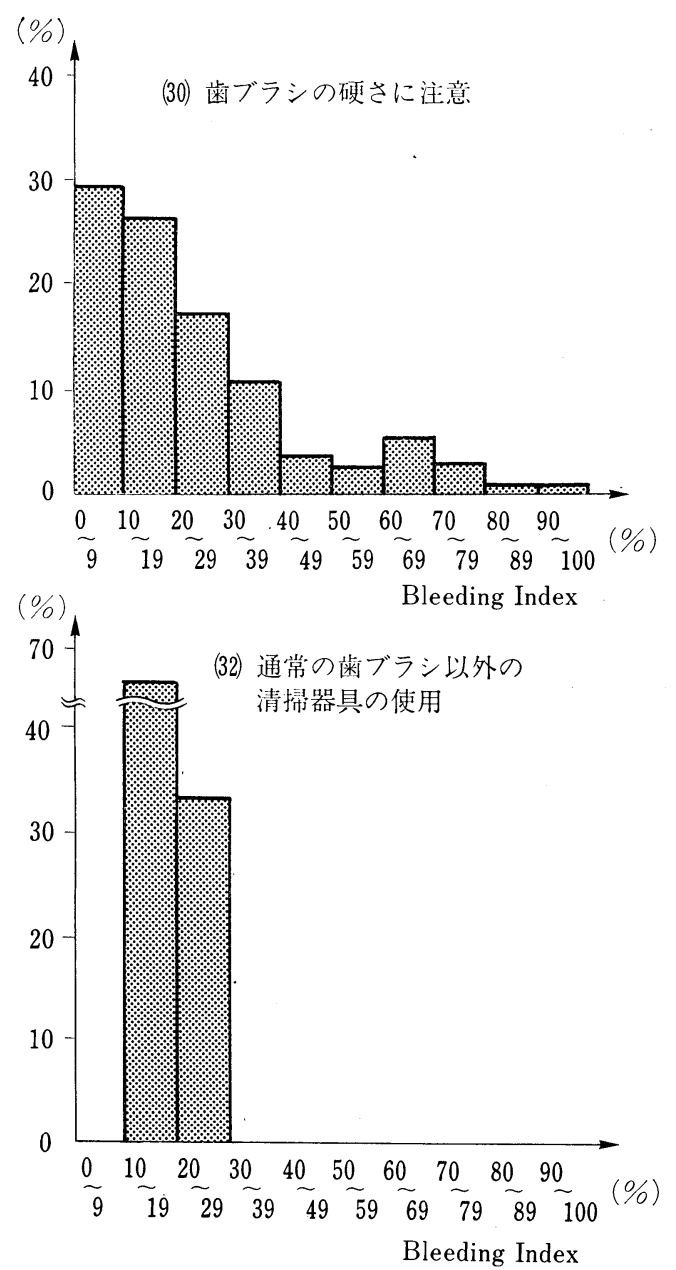
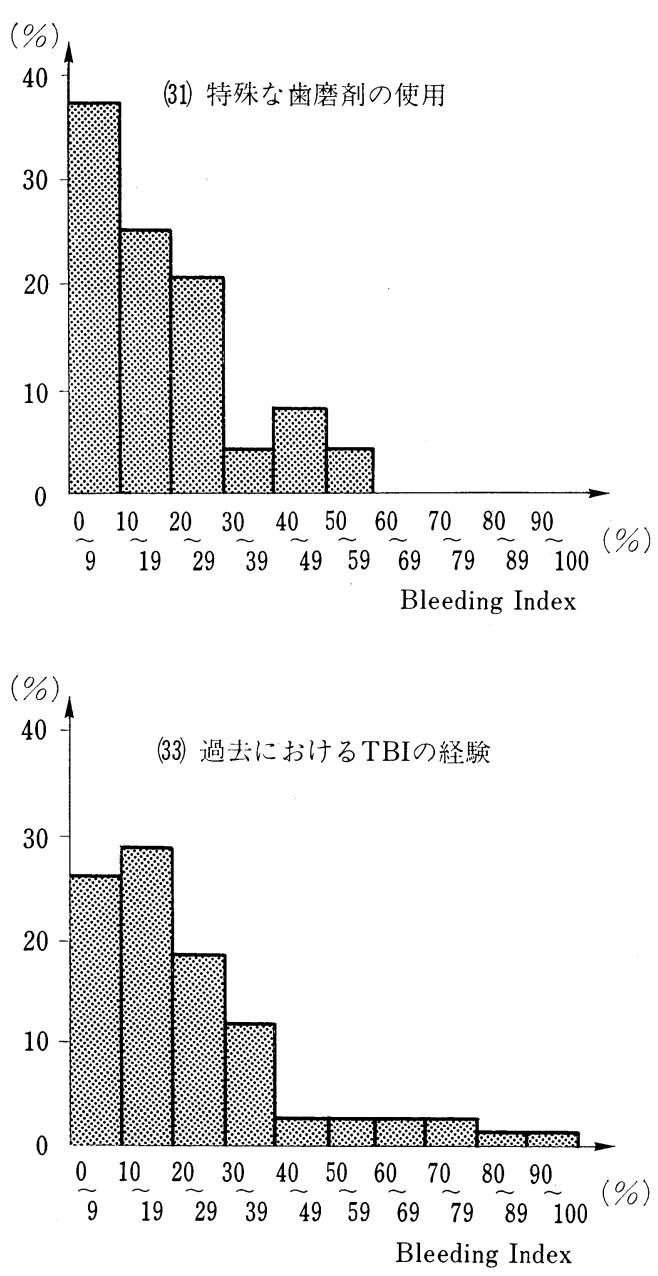

図 12 その他の口腔衛生観念と Bleeding Index

plaque の存在する部位に出血傾向が認められたと 報告 している。

以上まとめると, 歯肉出血指数は, 初期歯肉炎の発見 に有効であり，かつ鋭敏な指数であると結論づけること ができる。

今回われわれは, 昭和 51 年 6 月より昭和 59 年 2 月ま での間に当科を受診し慢性辺縁性歯周炎と診断された患 者, 男性 100 名, 女性 100 名を対象として歯肉炎出血指 数 Bleeding Index を中心に調查を行った。対象患者の 年齢は $24 \sim 67$ 歳で平均 46.4 歳であった。

初診時の B.I. の平均は $24.5 \%$ であり，0〜 $29 \%$ が全 体の $72.5 \%$ 占めていた。また男女別では, 男性の B.I. の平均は $22.8 \%$, 女性が $26.2 \%$ であり, 女性に B.I. の 高い傾向を認めたが統計的有意差は認められなかった。
また年代別にみた B.I. の平均では, 年齢による差は ほとんど認められず, 40 歳代と 50 歳代が $25.4 \%, 30$ 歳 代が $24.4 \%, 60$ 歳代 $24.2 \%, 20$ 歳代 $20.0 \%$ であり, 有 意差は認められなかった。

鎮守ら ${ }^{21)}$ は, 福岡地区に扮ける外来患者の疫学的調查 において Ainamo と Bay の Gingival Bleeding Index を使用して調查した結果, 30 代 $52.1 \%, 40$ 代 $42.3 \%, 50$ 代以上 $41.2 \%$ と 30 代が他の 2 者に比較して有意に高 く, 増齢的な歯肉出血率の減少が認められたと報告し, さらに 30 代の歯周疾患の臨床所見の特長は炎症像であ り, Gingival Bleeding Index や歯肉溝滲出液及び排膿 が高い值を示し, 50 代以上では歯周組織の破壊像が主体 となり, 歯牙の動摇や根分岐部病変が高率に認められ, 40 代はこの 2 者に比べ軽度の患者が多いように思われ 

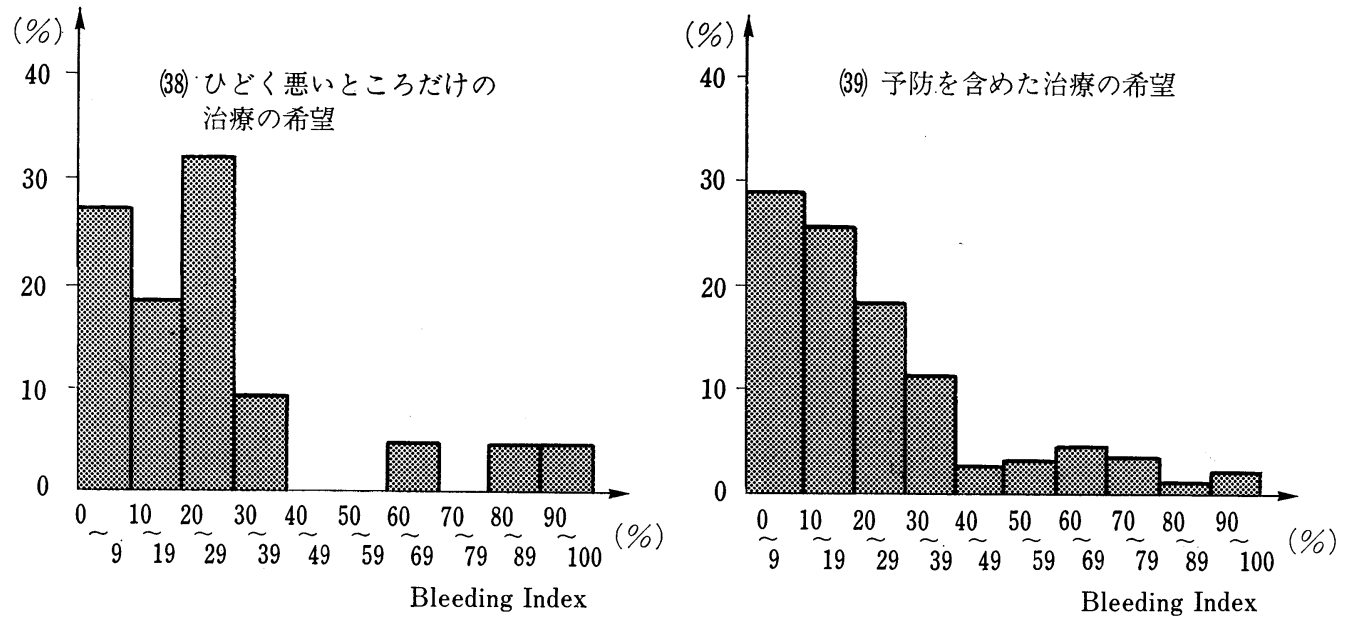

図 13 治療に対する熱意と Bleeding Index

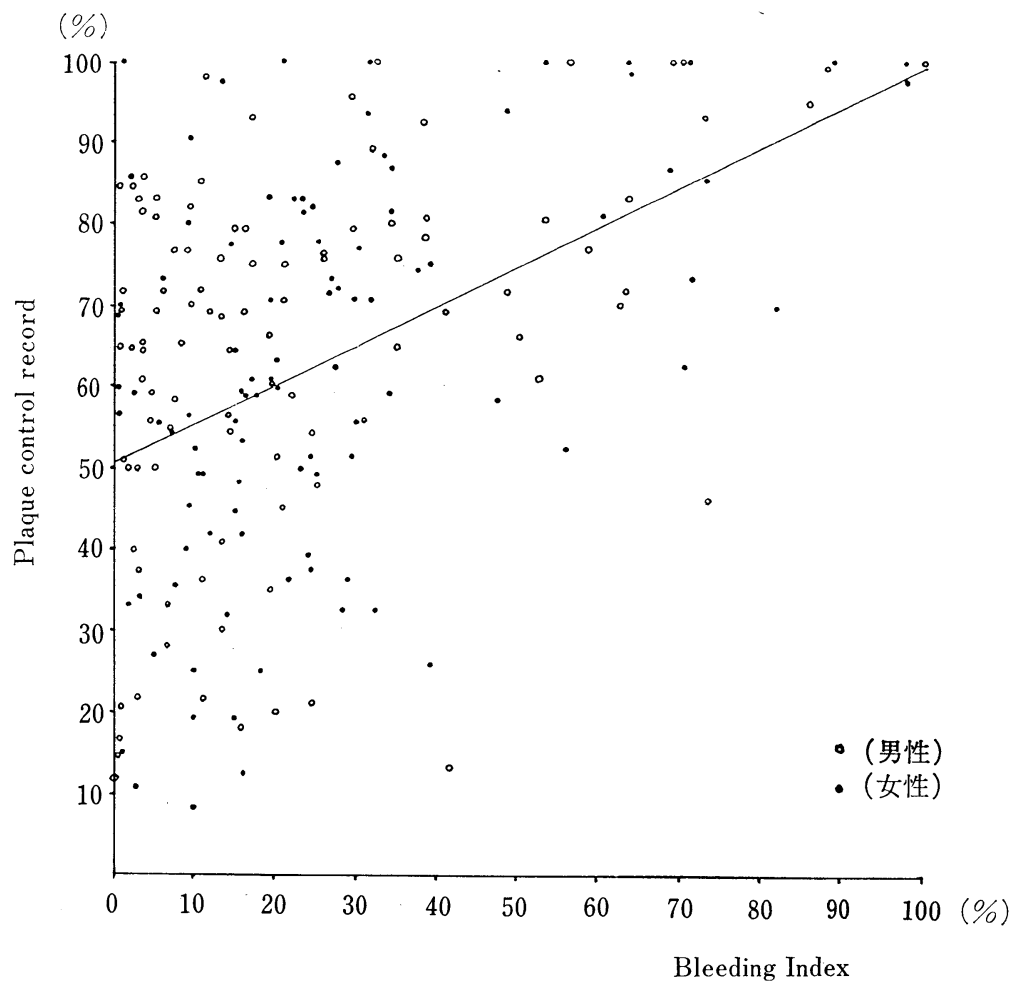

図 14 Plaque control record と Bleeding Index

たと考察している。

また渡辺ら ${ }^{20)}$ は生活環境や労動環境について多くの共 通性を有する工場従業員の疫学的調査において, Gingival Bleeding Index に男女的な統計的有意差は認められ
ず，年齢別では $40 \sim 50$ 代の中高年齢層に高い出血 傾 向 を認めたと報告している。

昭和 56 年の歯科疾患実態調査報告 ${ }^{22)}$ においても，年 齢階級別にみた歯肉の炎症のある者の率では，50〜 54 


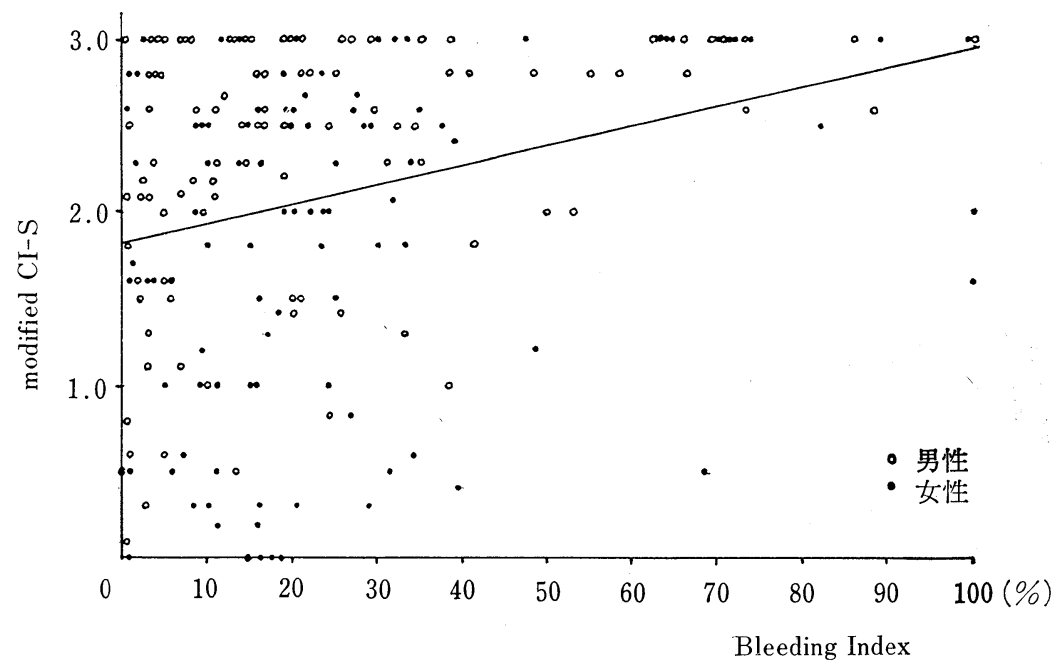

図 15 Modified CI-S そ Bleeding Index

歳が最も高く $68.0 \%$ を示し, 次いで 45 49歳で 65.1 $\% ， 40 \sim 44$ 歳で $62.8 \%$ となっている。

われわれの調查では男女別や年齡別にみた B.I. の平 均に差は認められなかったが, 先に報告した, P.C.R. ${ }^{3)}$ や歯石付着状態) の結果でも男女差は認められず，いず れも加齢と共に P.C.R. や歯石指数が高くなる傾向を認 めたが, 統計的有意差は認められなかった。これは当科 に来院した患者の初診時の疾患の進行度においても, 重 度 $57.5 \%$, 中等度 $35.0 \%$, 軽度 $7.5 \%$ と, 比較的疾患の 進行している患者が来院していることと, 新潟県と全国 の歯周疾患罹患患者率 ${ }^{33}$ では, 25 歳以上のすべての年齢 で全国平均より高い罹患率を示しているという地域性の あらわれとも考えられる。

疾患の進行度別の B.I. の平均を比較してみると, 軽 度は $16.4 \%$, 中等度 $21.4 \%$, 重度 $28.0 \%$ と疾患が進行 するにつれ B.I. が高くなる傾向が認められ, 軽度と重 度との間には, 統計的有意差が認められた。

次に歯周疾患患者質問調査表の各項目と B.I. との関 係について考察してみると, 患者の自覚症状において, 歯肉出血とブラッシング時の歯肉出血を訴えて来院する 患者は，それぞれ $63.0 \%, 70.5 \%$ と非常に高い割合で主 訴となる場合が多く,すでに報告した初診時来院の主訴 では食片圧入, ブラッシング時の歯肉出血, 歯肉出血, 排膿の順2)で, これらは浦 ${ }^{24)} ら の$ 離島および大学の付属 病院を受診した新来院患者の疫学調査と同様の結果を示 しており, 食片圧入と歯肉出血をかなりの割合で自覚し て来院している。また, この報告で興味深いことは, 最
も早く発現したと思われる症状は歯肉出血と食片圧入を

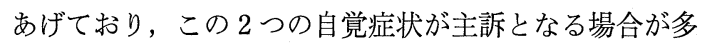
いと考えられる。

また, 同様に新谷ら ${ }^{25}$ は, 大学病院に来院した理由で “歯ぐきから血が出る”が一番多く $55.5 \%$ を占め主訴で ある割合が一番高かったとし, 歯肉よりの出血は比較的 患者自身も自覚しやすい症状であることを示している。

しかし患者の自覚した各項目と歯肉出血やブラッシン グ時の歯肉出血の B.I. の平均は有意差が認められず, 歯肉出血を自覚しているからといって B.I. が特に高い といらわけではなかった。

習慣および暂好品については, 硬固物を好む患者の B.I. の平均は有意に低い值を示した。

これは食物の嗜好について疾患の程度が進行する程, 甘い者を好む割合が増加し, 熱い物, 硬い物を好む割合 が減少する傾向を認めたという報告25)より推察すると, 硬固物を好む物は比較的疾患が進行しておらず， B.I. が 低かったのではないかと考えられる。しかし習慣や嗜好 品と B.I. を直接関連づけることは難しいと考えられた。 また口呼吸をする患者は B.I. が高い值を示し，口呼 吸患者では歯肉炎が強いという報告 ${ }^{26)}$ と一致していた。

過去における治療経験と B.I. については, スケーリ ングの既往のあるものは $66.6 \%$, 歯肉の治療の既往のあ るものは $29.0 \%$ と高い割合で治療を受けているが，そ の B.I. の平均はスケーリング経験者は $27.1 \%$, 歯肉の 治療経験者は $26.0 \%$ と比較的高值を示し, その治療が あまり奏効していないのではないかと考えられた。質問 
調査表からでは, 歯肉の治療の内容やブラッシング指導 の内容などとの関係は明確ではないが，第 3 報4) と同 様, やはりプラークコントロールの重要性が未だ広く認 識されず, 歯科医師側においてもスケーリングや歯肉の 治療を行ってもブラッシング指導はあまり有効に行われ ていないことが推察できる。

1 日のブラッシング回数と B.I. については, 1 日のブ ラッシング回数を 2 回と答えたものが最も多くその B.I. の平均は, 3 回のものが最も多く $27.0 \%, 2$ 回 $24.6 \%, 1$ 回 $24.0 \%$ でこれらの間に有意差は認められなかったが, ブラッシング回数が少なくなるにつれて B.I. の值が低 くなるという意外な傾向を認めた。これは 1 日の刷掃回 数と歯面清掃状態と歯肉の健康状態との間には相関関係 はないとしている多くの報告と一致27,28)している。また 新谷ら ${ }^{25)}$ は歯磨きの回数について, 女性では歯磨きの回 数が多い程, 疾患が進行している割合が多いが, 歯磨きの 回数と疾患の程度との間に有意差はなかったと報告して おり, 疾患の程度は歯磨きの回数よりも, 本質的には口 腔清掃状態の内容による影響が大きいと考察している。

われわれの結果も同様の傾向が認められ, 歯肉出血が 患者の自覚として最も強く, 歯肉より出血する場合, ブ ラッシングに注意するため 1 日のブラッシング回数が多 くなるのではないか, またブラッシングの習慣も定着し ておらず，正しいブラッシング方法も普及していないこ とがこれらの結果を得たのではないかと考えられた。正 しいブラッシング方法や正しい口腔衛生観念の指導や普 及の必要性を痛感した。

歯ブラシの交換頻度と B.I. については, 歯ブラシの 交換をあまりしない患者の B.I. は最も高く $27.7 \%$ であ り，やはり口腔清掃やブラッシングに興味のない患者は 歯肉炎の程度も高いように思われた。

前述の浦ら ${ }^{24)}$ にると, 歯ブラシの使用期間は離島の 患者では 1 カ月から 6 力月, 大学病院の患者で 1 力月か ら 2 カ月がほとんどであったと報告しており，われわれ と同様の結果であった。

Glaze と Wade による29) と, 歯ブラシの寿命と劣化 がプラーク除去にどの位, 影響するか研究した結果, や はり連続約 10 週程度使用した歯ブラシはプラーク 除去 効果の低下を認め, またそれはかなりの個人差を認めた とし, 定期的な歯ブラシの交換の必要性を示唆してい る。

また Glass と Lare ${ }^{30)}$ の報告では, 歯ブラシは約 1 カ 月使用すると細菌で污染される可能性があることを示唆 し, これらの污染歯ブラシは全身性や局所性の疾患の原
因になるかもしれないと述べている。

このように歯ブラシの交換頻度も歯肉炎の程度に影響 すると思われる。

その他の口腔衛生観念と B.I. については, 特殊な歯 磨剂を使用している患者, 通常の歯ブラシ以外の清掃器 具を使用している患者の B.I. の平均はいずれも $18.3 \%$ と低く歯肉炎の程度も低いと考えられた。

治療に対する熱意との関係については，予防を含めた 治療を希望する患者の方が，ひどく悪いところだけの治 療を希望するものより B.I. の平均は低い值を示し，歯 石付着状態と同様の結果を得た。

今回調查した 200 名は, 全身疾患を有していない患者 を対象としたが，血液疾患患者や糖尿病患者などでは， プロービング時の出血量が健常者に比べ 2 倍以上大きい 值を示し，これらの患者は健常者と同一基準に立って考 えることはできないという報告 ${ }^{11}$ があり，初診時の問診 の大切さがうかがえる。

歯石付着状態と疾患の進行度との関係では疾患が進行 するにつれて高くなる傾向がみられ，統計的有意差を認 めた ${ }^{4)}$ 。一方 P.C.R. については, 疾患の進行度との関 連性は認めることができなかった ${ }^{3)}$ 。これはプラーク付 着状況は日時による差があり変化するものであるため で, 歯石付着状態は過去からの蓄積の結果であり, 慢性 進行性疾患の状態を反映するもので, さらに歯肉出血指 数は, 来院直前のブラッシングの使用に左右されず, かつ歯肉の炎症の程度に鋭敏に反応することより，疾患 が進行するにつれて, B.I. が高い傾向を示すと考えられ る。

\section{結＼cjkstart論}

昭和 57 年 6 月より昭和 59 年 2 月までの間に日本歯科 大学新潟歯学部歯周治療科江来院し, 慢性辺縁性歯周炎 と診断された患者 200 名（男性 100 名，女性 100 名）を 対象として初診時の歯肉出血指数について検索を行い以 下の結果を得た。

1. 初診時の B.I. の平均は $24.5 \%$ であり, B.I. が 0〜9\%は $29.5 \%, 10 \sim 19 \%$ が $25.0 \%, 20$ 29\% が 18.0 \%の順であり，0〜29\% が全体の $72.5 \%$ を占めていた。

2. 男女別にみた B.I. の比較では, 男性の B.I. の平 均は $22.8 \%$, 女性が $26.2 \%$ であり, 分布に括いても女性 に高い傾向を認めたが，有意差は認められなかった。

3. 年代別にみた B.I. の比較では, 40 歳代と 50 歳代 $25.4 \%, 30$ 歳代 $24.4 \%, 60$ 歳代 $24.2 \%, 20$ 歳代 $20.0 \%$ 
と年歳による差はほとんど認められず，統計的有意差は 認められなかった。

4. 疾患の進行度との関係では, 軽度 $16.4 \%$, 中等度 $21.4 \%$, 重度 $28.0 \%$ と疾患が進行するにつれて B.I. が 高くなる傾向を認め, 軽度と重度の間に有意差を認め た。

5. 歯周疾患患者質問表の各項目と B.I. との関係で は,

1）自覚症状に氺いて B.I. の平均は歯肉出血を訴え る者は $25.9 \%$, 歯肉腫脹 $27.5 \%$, ブラッシング時の歯肉 出血 $24.2 \%$, 咀嚼障害 $28.1 \%$ と比較的高い值がみられ たが，それぞれの間に有意差は認められなかった。

2）習慣および㖺好品との関係では，硬固物を好む者 の B.I. の平均は有意に低い值を示した。また口呼吸を する者は $26.6 \%$ と比較的高い值を示した。

3）過去に扔ける治療経験との関係では，スケーリン グの既往のある者の B.I. の平均は $27.1 \%$, 歯肉の治療 の既往のある者 $26.0 \%$ と比較的高い值を示したが有意 差は認められなかった。

4） 1 日のブラッシング回数の B.I. の平均は, 3 回の ものが $27.0 \%, 2$ 回 $24.6 \%, 1$ 回 $24.0 \%$ とブラッシング 回数が少なくなるにつれて B.I. の值が低くなる傾向を 認めたが，これらの間に有意差は認められなかった。

5）歯ブラシの交換をあまりしない患者の B.I. の平 均は $27.7 \%$ と最も高かった。歯ブラシを 3 カ月ぐらい で交換するものと， 2 力月およびあまり交換しないもの との間で有意差を認めた。

6）特殊な歯磨剤を使用している患者, 通常の歯のブ ラシ以外の清掃具を使用している患者の B.I. の平均は $18.3 \%$ と有意に低い値を示した。ブラッシング指導経験 者の B.I. の平均は $24.0 \%$ であり統計的有意差は認めら れなかった。

7）治療に対する熱意では，予防を含めた治療を希望 する患者の B.I. の方が低い值を示したが，統計的有意 差弪められなかった。

6. プラーク付着状態, 歯石付着状態と B.I. との間 に危険率 $1 \%$ 以下で有意差が認められ，B.I. と P.C.R., B.I. と modified CI-S の間に正の相関関係を認めた。

\section{文献}

1）鴨井久一, 吉永英司 : 歯肉溝にみられる臨床 所 見. 歯科ジャーナル， $17: 37-43,1983$.

2）上野益卓, 岡部秋彦, 玉井憲二, 佐藤昌司, 三上
格, 河野昭彦, 媣井浩一, 高橋克弥, 大滝晃一, 長谷川明 : 歯周疾患 (慢性辺縁性歯周炎) 患者の 初診時診査項目に関する検討 第 1 報 歯周疾患 患者質問調查表について. 日歯周誌, $27: 618$ 634, 1985.

3）玉井憲二, 上野益卓, 岡部秋彦, 佐藤昌司, 三上 格, 河野昭彦, 深井浩一, 高橋克弥, 大滝晃一, 長谷川明 : 歯周疾患 (慢性辺縁性歯周炎) 患者の 初診時診査項目に関する検討 第 2 報 プラーク 付着状態について. 日歯周誌, $27: 890-901,1985$.

4）岡部秋彦, 上野益卓, 玉井憲二, 佐藤昌司, 三上 格, 河野昭彦, 深井浩一, 高橋克弥, 大滝晃一, 長谷川明 : 歯周疾患 (慢性辺縁性歯周炎) 患者の 初診時診査項目に関する検討 第 3 報 歯石付着 状態について. 日歯周誌, $28: 704-719,1986$.

5) Löe, H. and Silness, J. : Periodontal disease in pregnancy, 1. Prevalence and severity. Acta. Odont. Scand., $21:$ 533-551, 1963.

6) Muhlemann, H.R. and Son, S. : Gingival Sclcus bleeding-a leading symptom in initial gingivitis. Helv. Odont. Acta., $15: 107-113,1971$.

7) Ainamo, J. and Bay, I. : Problems and proposal for recording gingivitis and plaque. Int. Dent. J., $25: 229-235,1975$.

8) Van Der Velden, U. : Probing force and the relationship of the probe tip to the periodontal tissues. J. Clin. Periodont., 6 : 106-114, 1979.

9）神山義信, 浅沼 勝, 徳崇昇一, 前田久美子, 染 川誠郎, 堀内 博：ヒトの実験的歯肉炎における Bleeding index について. 日歯周誌, $23: 518$ 525, 1981.

10）高須賀慎二, 花村裕之, 本田 忍, 吉永英司, 保 母良基, 亘理 滋, 鴨井久一：Gingival Bleeding Index の再評価について. 日歯周誌, $23: 664-668$, 1981.

11）䞇 良治, 勝谷芳文, 堀口優美, 田中龍男, 梶川 潔, 村上純一, 西川博之, 河内準治, 白木雅文, 岩田 真, 山田 亨, 岩山幸雄 : ヒトの実験的歯 肉炎に扔ける各種臨床的指数の再評価. 日歯周誌, $25: 830-836,1983$.

12）鴨井久一，花村裕之，宮本美彦：プローブによる 歯肉の評価法. 歯科 ジャーナル, $16: 489-497$, 1982.

13) Sivertson, J.F. and Burgett, E.G. : Probing of 
pockets related to the attachment level. J. Periodontal., 47 : 281-286, 1976.

14) Armitage, G.C., Svanberg, G.K. and Löe, H : Microscopic evaluation of clinical measurements of connective tissue attachment levels. J. Clin. Periodontol., 4 : 173-190, 1977.

15) Van der Velden and Jensen, J. : Probing force in relation to probe penetration into the periodontal tissues in dogs. J. Clin. Periodontol., $7: 325-327,1980$.

16) Polson, A.M. and Goodson, J.M. : Periodontal Diagnosis, current status and future needs. J. Periodontol., 56 : 25-34, 1985.

17) Listgarten, M.A. : Periodontal probing; what dose it mean ? J. Clin. Periodontol., $7: 165-176$, 1980.

18) Freed, H.K., Gapper, R.L. and Kalkwarf, K.L. : Evalution of periodontal probing force. J. Periodontol., $54: 488-492,1983$.

19) Meitner, S.W., Zander, H.A., Iker, H.P. and Polson, A.M. : Indentification of inflamed gingival surfaces. J. Clin. Periodontol., 6 : 93-97, 1979.

20）渡辺嘉一，高須賀慎二，松田文英，宮田裕之，若 尾徳男, 川村 真, 鴨井久一 : 歯周疾患に関する 疫学的調查 (第 1 報). 日歯周誌， $24: 446-455$, 1982.

21）鎮守信弘, 前田勝正, 原 宜興, 古川猛士, 相田 宜利, 鄭 有仁, 谷季実子, 宮武祥子, 畠山民子, 山田久仁子, 大賀信之, 北村哲朗, 戸田佳子, 赤 峰昭文, 青野正男 : 福岡地区における歯周疾患の 疫学的研究（第 1 報）外来患者の歯周疾患罹患状
態について. 日歯周誌, 28 : 681-691， 1986.

22）厚生省医務局歯科衛生課編 : 昭和 56 年歯科 疾 患 実態調查報告，口腔保健協会 : 23-31，1981.

23）新潟県歯科保健医療対策委員会 : 新潟県県民歯科 疾患実態調查報告書, 1983 .

24）浦浩二郎，永松 敬，国松和司，岡本行人，清水 満廣, 小鷲悠典, 加藤伊八 : 長崎県小離島の口腔 疾患に関する疫学的研究 問診表による歯周疾患 に関する調査結果. 日歯周誌, $26: 757-766,1984$.

25）新谷史子，中嶋美紀子，塩野宗則，大場浩二，新 井 高, 中村治郎 : 歯周疾患患者の問診表の統計 的観察. 日歯周誌， $24: 165-175,1982$.

26）上野益卓，佐藤昌司，三上 格，松村正昭，大滝 晃一，長谷川明：口呼吸によって下䫟前歯唇側歯 肉部に発現したと思われる歯肉炎とその治療経 過. 日歯周誌, $26: 602,1984$.

27）山田 茂, 島田 正, 江間誠二，小山 哲，市川 和博, 荘 仁智 : 中学校生徒における刷掃回数, 歯面清潔度, PMA 指数 3 者間の相関. 口衛誌, 26 : 271-279, 1977.

28）中久木正俊, 岸孝一郎, 三宅次夫, 飲沼政義, 伊 藤 忠: 刷掃回数と歯口清掃度の相関. 日大歯学, 41 : 753-754, 1967.

29) Glaze, P.M. and Wade, A.B. : Tooth brush age and wear as it relates to plaque control. J. Periodontol., $13: 52-56,1986$.

30) Glass, R.T. and Lare, M.M. : 歯ブラシの細菌污 染は健康に害があるのか？ The Quintessence, 5 : 1631-1636, 1986.

31）神山義信 : Bleeding Index を用いた歯周疾患の 診断法に関する研究 II. 血液疾患患者および糖 尿病患者への応用. 日歯周誌, $27: 541-553,1985$. 